\title{
Growth and Survival in Nursery Rearing Phase of the Asian Seabass (Lates calcarifer, Bloch) under Different Stocking Densities in Floating Net Cages
}

\author{
G. Suresh ${ }^{1 *}$, M. Raveendra ${ }^{2}$, K. Jyotsna Rajeswari ${ }^{3}$, B. Chamundeswari Devi ${ }^{4}$,
} M. Anusha ${ }^{4}$, D. Venkatesh ${ }^{1}$, D. Ravindra Kumar Reddy ${ }^{1}$ and N. Madhavan ${ }^{1}$

${ }^{1}$ College of Fishery Science, Muthukur, Nellore, Sri Venkateswara Veterinary University, Tirupati, Andhra Pradesh, India

${ }^{2}$ Krishi Vigyan Kendra, Lam, Guntur, Sri Venkateswara Veterinary University, Tirupati, Andhra Pradesh, India

${ }^{3}$ Kerala University of Fisheries and Ocean studies (KUFOS), Panangad, Kochi, Kerala, India

${ }^{4}$ Fisheries Research Station, Kakinada, Sri Venkateswara Veterinary University, Tirupati, Andhra Pradesh, India

*Corresponding author

\section{A B S T R A C T}

\section{Keywords}

Asian seabass, Growth, Survival, Stocking density, Cage culture

Article Info

Accepted: 16 April 2018 Available Online: 10 May 2018
This study was conducted to study the effect of stocking density on growth and survival of seabass, Lates calcarifer in floating net cages in closed bay, Bapatla, Andhra Pardesh, India. Triplicate groups of seabass with an average initial weight of $1.29 \pm 0.12 \mathrm{~g}$ were randomly stocked in floating net cages $(1 \mathrm{~m} \times 1 \mathrm{~m} \times 2 \mathrm{~m})$ at $20,40,60$ and 80 fish/m3designated as SD20, SD40, SD60 and SD80 respectively. Seabass in the cages were fed with $45 \%$ CP formulated diet at $10 \%$ of body weight twice daily. Sampling was done weekly. At the end of the stocking trail, growth in terms of body weight, weight gain, specific growth rate and survival rate of fish was high in SD20 than those in SD40, SD60 and SD80. Total Feed conversion ratio was lower in SD20 followed by SD40, SD60 and SD80. The cages stocked with $20 \mathrm{fish} / \mathrm{m}^{3}$ have highest growth performance and survival. $20 \mathrm{fish} / \mathrm{m}^{3}$ showed better survival percentage than SD40, SD60 and SD80. Water quality parameters were at optimum level during study period. Results suggest that $20 \mathrm{fish} / \mathrm{m} 3$ could be recommended for producing better quality seabass fingerlings and $80 \mathrm{fish} / \mathrm{m} 3$ for highest number of seed production.

\section{Introduction}

Cage culture is an alternative to inland and brakish water farming, whereby existing water resources are used to increase fish and shell fish production and the fish are enclosed in a cage allowing the water to pass freely between the fish in the sea. In India, on a global scale also, the decline of fish stocks has been a motivating factor for expanding the role of aquaculture (Baldwin et al., 1999). The system of cage farming has an important role in meeting the global demand for fish products (Fredriksson et al., 1999). Marine aquaculture is a growing industry worldwide (WRI, 1998) due to the increasing demand for marine 
products by the human population. Asian seabass, Lates cacarifer is an euryhaline, protandric hermaphrodite, carnivorous with a cannibalistic character. It is relatively hardy species that tolerates crowding and has wide physiological tolerances including high turbidity, varying salinities and temperature (Boonyatarpalin, 1997; Yue et al., 2009).

Seabass is farmed in both brackishwater and freshwater ponds, as well as in cages of coastal waters in Malaysia, Indonesia, Thailand, Taiwan and in Australia. According to Boonyaratpalin and Williams, (2002) cage culture of this species is preferred over pond culture. In cage culture stocking densities of species are highly variable and little research was done to establish the optimum stocking density for many species (Beveridge, 2004). Stocking density is one of the factors that could potentially affect survival and production performance of aquatic organisms.

Thus, the use of an appropriate density can increase the profitability of farming systems, by maximizing the utilization of water and the other resources in the rearing system (Fairchild and Howell, 2001). In cage aquaculture, fish stocking density has great impact on growth, survival, health, water quality and production (Costa et al., 2013). Consequently, optimum stocking densities need to be determined for each species and production phase to enable efficient management and to maximise production and profitability.

Stocking density also depends on the carrying capacity of the cages. Optimal stocking density varies with species and size of fish stocked (Brown, 1946; Chua and Teng, 1979). In cage culture practices determination of the optimal stocking rate becomes an important part because stocking density directly influences the growth rate of the cultured species (Kilambi et al., 1977). However no information is available on the effect of stocking density on survival and growth performance of Asian seabass fingerlings reared in floating net cages. Hence the present study envisaged to investigate the effect of stocking density on survival and growth of Asian seabass held at four different stocking densities in floating net cages.

\section{Materials and Methods}

\section{Experimental site}

The present study was conducted in the closed bay near Suryalanka, Bapatla, Guntur district. It lies between latitude- $15^{\circ} 51^{\prime} 04.54^{\prime \prime} \mathrm{N}$ and longitude $80^{\circ} 31^{\prime} 58.87^{\prime}$ 'E.The experimental site is shown in Figure 1.

\section{Experimental fishes}

Seabass seed (Figure 3) was procured from the private hatchery at Kakinada, Andhra Pradesh. Seed was transported by train in plastic bags containing water of $30 \mathrm{ppt}$ salinity. The seed was conditioned on the previous day of transportation without any feeding. Seed was acclimatized to the rearing conditions by keeping the polythene bags containing the seed in hapas for about $15 \mathrm{~min}$ followed by slow addition of water from the bay to the polythene bag before releasing seed into floating net cages.

\section{Experimental cages}

The floating net cages used for experiment was of $20^{1} \times 10^{1}$ (Hapas of $1 \mathrm{~m} \times 1 \mathrm{~m} \times 2 \mathrm{~m}$ size, fine-meshed polyethylene (PE) net cages $(1.25$ $\mathrm{mm}$ ) were fixed in the cages). Outer cage made up of high density polyethylene (HDPE) was used as protection from predators (Predatory net). The net cages were fixed to a bamboo raft. The bamboo raft was used for easy movement, feeding and sampling of the experimental fishes on the cage structure. 
Sealed and air filled plastic drums of 200 litre size were used as cage float for buoyancy of cage structure. Each cage was covered at the top with a piece of large mesh size $(4.5 \mathrm{~cm})$ net to prevent escape of fish by jumping and predation of birds as reported by Moniruzzaman et al., (2015b). The top of portion of each experimental hapa was covered with a fine mesh net up to $20 \mathrm{~cm}$ depth to prevent floating feeds from escaping the hapa and the whole structure was tied with anchors at each corner by nylon rope to make easy movement of floating cages depending on water level and flow. The cages were positioned in closed bay $500 \mathrm{~m}$ away from the shore with moderate water flow $(0.05$ m.second $\left.{ }^{-1}\right)$. The submerged volume of the cages was invariably $1 \mathrm{~m}^{3}$. Fishes were acclimated with the sea environment by rearing them in hapa net for one week. Fish with an average initial weight of $1.29 \pm 0.12 \mathrm{~g}$ were randomly stocked in the net cages at 20 $\mathrm{fish} / \mathrm{m}^{3}, 40 \mathrm{fish} / \mathrm{m}^{3}, 60 \mathrm{fish} / \mathrm{m}^{3}$ or $80 \mathrm{fish} / \mathrm{m}^{3}$ as SD20, SD40, SD60 and SD80, respectively, in triplicates. The experimental setup is shown in Figure 2.

\section{Feed}

Formulated floating feed with $45 \%$ crude protein was used for feeding. Feed was prepared with groundnut cake (GNC) at $47 \%$, fish meal (FM) at $47 \%$, de oiled rice bran (D.O.B) at $2 \%$, wheat flour at $2 \%$ and $2 \%$ of vitamin and mineral mixture were added. Feed was estimated for proximate composition (AOAC, 1995). Feed was applied at the rate of $10 \%$ of body weight. Fish were fed twice a day at 8:00 hr. and at 16:00 hr. with each daily ration divided into two equal halves. Feeding was done manually to ensure ingestion of feed completely by the fish. Fish in each treatment was sampled weekly to obtain weight of fish and the feed amount to be given was adjusted accordingly. The experiment lasted for 63 days.

\section{Water quality parameters}

Water quality parameters like temperature (Celsius glass thermometer), salinity (Hand held Refractometer), dissolved oxygen (Titrimetric, Winkler's method APHA, 1995), $\mathrm{pH}$ (Digital pH meter), Alkalinity, Ammonia, Nitrite and Nitrate (APHA, 1995) were measured at $8.00 \mathrm{hrs}$ on weekly basis. Water samples were transported to the laboratory after collection and analysed.

\section{Management of cages}

The cages were removed from water at every 15 days interval to check the net and cleaning purpose. Cages were cleaned regularly to remove algae, polychaetes and other organisms. Dead fish were removed from cages immediately and disposed off in a pit. Ancillary works like mending of torn nets and realignment/readjustment of sinkers and anchors were also performed for proper management of cages (Figure 4).

\section{Cage fouling}

During the present study, it was observed that the fish and crustacean population around the cages increased. Algae, polychaetes, green mussels and other molluscs were the main biofouling organisms on the net of the cage.

\section{Fish samplings}

Individual fish samples were randomly taken weekly for enumeration of various growth parameters as below:

Weight increment $=$ Final body weight $(\mathrm{g})-$ Initial body weight $(\mathrm{g})$.

Specific growth rate $(\mathrm{SGR})=\left[\left(\mathrm{L}_{\mathrm{n}} \mathrm{FBW}-\mathrm{L}_{\mathrm{n}}\right.\right.$ IBW) / day] $x$ 100, Where: $L_{n}=$ Natural logarithm, FBW = final body weight, IBW = initial body weight. 
Survival Rate $(\%)=$ Total number of fish survived / Total number of fish stocked $\times 100$

Feed Conversion Ratio $(\mathrm{FCR})=$ Feed given (dry weight) (g) / Body weight gain (wet weight) (g).

Average Daily Weight Gain $(\mathrm{ADWG})=$ Final fish weight $(\mathrm{g})$ - Initial fish weight $(\mathrm{g})$ / Number of days.

Biomass $=$ No. of fish $\times$ average body weight (g)

\section{Statistical analysis}

The data obtained on Growth, Weight Gain, Survival and Feed Conversion Ratio was treated statistically by applying two way ANOVA classifications according to Snedecor and Cochran (1989). The results were presented as mean \pm standard error (SE).

\section{Results and Discussion}

The details of the water quality parameters recorded during the study period in the floating cages are given in Table 1. The temperature, salinity, pH, D.O, Total alkalinity, Ammonia, Nitrite and Nitrate recorded in the cages were in the range 27.5 to $31.1^{0} \mathrm{C}, 22$ to $32 \mathrm{ppt}, 7.8$ to $8.3,4.3$ to 6.6 $\mathrm{mg} / \mathrm{l}, 138$ to $160 \mathrm{mg} / \mathrm{l}, 0.01$ to $0.25 \mathrm{mg} / \mathrm{l}, 0.01$ to $0.03 \mathrm{mg} / \mathrm{l}$ and 1.99 to $3.80 \mathrm{mg} / \mathrm{l}$ respectively. During the experimental period, increments of growth at weekly intervals are shown in Figure 3. On the final day the highest average weight gain was observed in the SD 20 followed by SD 40, SD 60 and SD 80. At the end of 63 days of fish rearing in floating net cages, biological preferences of Asian seabass at different stocking densities were presented in Table 2. All growth parameters in terms of final weight, weight gain, ADWG and SGR were significantly decreases from lower to higher stocking densities. Lower survival rate was found in SD 80 than those in SD 20, SD 40 and SD 60. Feed conversion ratio (FCR) was significantly increased with increasing stocking density. The best FCR was found for the lowest stocking density of SD 20 while highest in SD 80. Higher biomass was found in SD 80 followed by SD 60, SD 40 and SD 20.

In the present study water temperature was recorded between $27.5{ }^{0} \mathrm{C}$ to $31.1{ }^{0} \mathrm{C}$, pH 7.8 to 8.3 , dissolved oxygen 4.6 to $6.6 \mathrm{mg} / \mathrm{l}$, and salinity 22 to $31 \mathrm{ppt}$. The water quality parameters were within the limits cited by Rimmer and Russel (1998) for the rearing of Asian seabass nursery and grow-out. Bardach et al., (1972) found water temperature 24$38^{\circ} \mathrm{C}$, pH 7.1-7.9 and salinity $10-35 \mathrm{ppt}$ with good growth of sea bass. In this study, water quality parameters are in the suitable range for seabass. (Temperature $27.5-31.1^{\circ} \mathrm{C}, \mathrm{pH} 7.8-$ 8.3 and salinity 22-31 ppt). In the present study salinity of water is slowly decreased. This may be due to rains in that particular period and riverine inflow into the bay. In the present study, growth reduced with increasing stocking density.

The results are in agreement with studies conducted by Abou et al., (2007) reported that increasing stocking density of $O$. niloticus fry slowed down the growth. In grouper, red tilapia, African cat fish and largemouth bass fishes also mean weights and growth decreased with increasing stocking densities (Hengsawat et al., 1997; Petit et al., 2001). In the present study results was similar to that observations of Sadhu et al., (2015). They reported that growth, survival, average daily weight gain and SGR were higher in fish held in low stocking density $\left(14 / \mathrm{m}^{3}\right)$ when compared to high stocking density $\left(35 / \mathrm{m}^{3}\right)$. Seabass larvae reared in 51 capacity cylindrical plastic containers and maximum growth was observed in intermediate stocking density 8 no.l $^{-1}$ (Sukumaran et al., 2011). 
Table.1 Physico-chemical characters of the water samples from the experimental cages

\begin{tabular}{|c|c|c|c|c|c|c|c|c|}
\hline $\begin{array}{l}\text { Sampling } \\
\text { Days }\end{array}$ & $\begin{array}{c}\text { Tempe } \\
\text { rature } \\
(\mathbf{C})\end{array}$ & $\begin{array}{c}\text { Salinity } \\
(\mathbf{p p t})\end{array}$ & $\mathbf{p}^{\mathbf{H}}$ & $\begin{array}{c}\mathbf{D . O} \\
(\mathbf{m g} / \mathbf{l})\end{array}$ & $\begin{array}{c}\text { Total } \\
\text { Alkalinity } \\
(\mathbf{m g} / \mathbf{l})\end{array}$ & $\begin{array}{c}\text { Ammonia } \\
(\mathbf{m g} / \mathbf{l})\end{array}$ & $\begin{array}{c}\text { Nitrite } \\
(\mathbf{m g} / \mathbf{l})\end{array}$ & $\begin{array}{l}\text { Nitrate } \\
(\mathbf{m g} / \mathbf{l})\end{array}$ \\
\hline Initial & 27.5 & 27 & 8.2 & 6.6 & 148 & 0.01 & 0.01 & 2.95 \\
\hline $\mathbf{7}$ & 29.4 & 31 & 8.3 & 5.5 & 154 & 0.01 & 0.02 & 2.65 \\
\hline $\mathbf{1 4}$ & 29.1 & 30 & 8.2 & 5.4 & 152 & 0.02 & 0.03 & 3.80 \\
\hline $\mathbf{2 1}$ & 30.3 & 30 & 7.8 & 5 & 149 & 0.25 & 0.01 & 1.99 \\
\hline $\mathbf{2 8}$ & 28.6 & 29 & 8 & 5.5 & 160 & 0.05 & 0.02 & 2.20 \\
\hline $\mathbf{3 5}$ & 28.5 & 28 & 7.8 & 4.6 & 159 & 0.25 & 0.03 & 3.30 \\
\hline $\mathbf{4 2}$ & 31.1 & 28 & 7.8 & 5.2 & 138 & 0.02 & 0.01 & 2.95 \\
\hline $\mathbf{4 9}$ & 28.3 & 26 & 8.1 & 4.3 & 151 & 0.01 & 0.02 & 2.60 \\
\hline $\mathbf{5 6}$ & 28.5 & 23 & 8.1 & 5.3 & 160 & 0.25 & 0.03 & 2.94 \\
\hline
\end{tabular}

Table. 2 Growth performance, survival, specific growth rate, feed conversion ratio, Average daily weight gain and biomass of Asian seabass in floating net cages after 63 days of experimental period

\begin{tabular}{|c|c|c|c|c|}
\hline \multicolumn{1}{|c|}{ Treatments } & SD 20 & SD 40 & SD 60 & SD 80 \\
\cline { 1 - 5 } Parameters & & & & \\
\hline Initial weight(g) & $1.28 \pm 0.12$ & $1.30 \pm 0.14$ & $1.25 \pm 0.11$ & $1.35 \pm 0.13$ \\
\hline Final weight(g) & $21.51 \pm 0.14$ & $19.32 \pm 0.10$ & $15.43 \pm 0.16$ & $13.60 \pm 0.15$ \\
\hline Weight gain (g) & $20.26 \pm 0.11$ & $18.02 \pm 0.15$ & $14.18 \pm 0.10$ & $12.25 \pm 0.16$ \\
\hline Survival (\%) & 70 & 60 & 56.60 & 48.75 \\
\hline SGR (\%) & $2.72 \pm 0.06$ & $2.53 \pm 0.04$ & $2.38 \pm 0.03$ & $2.13 \pm 0.02$ \\
\hline FCR & $2.27 \pm 0.06$ & $2.28 \pm 0.08$ & $2.53 \pm 0.04$ & $2.60 \pm 0.09$ \\
\hline ADWG(g) & $0.321 \pm 0.03$ & $0.284 \pm 0.02$ & $0.225 \pm 0.03$ & $0.194 \pm 0.01$ \\
\hline Biomass(g) & $301.14 \pm 0.22$ & $461.28 \pm 0.16$ & $524.62 \pm 0.19$ & $530.40 \pm 0.18$ \\
\hline
\end{tabular}

Fig.1 Growth increment of Asian seabass at different stocking densities on each sampling day over 63 days of experiment

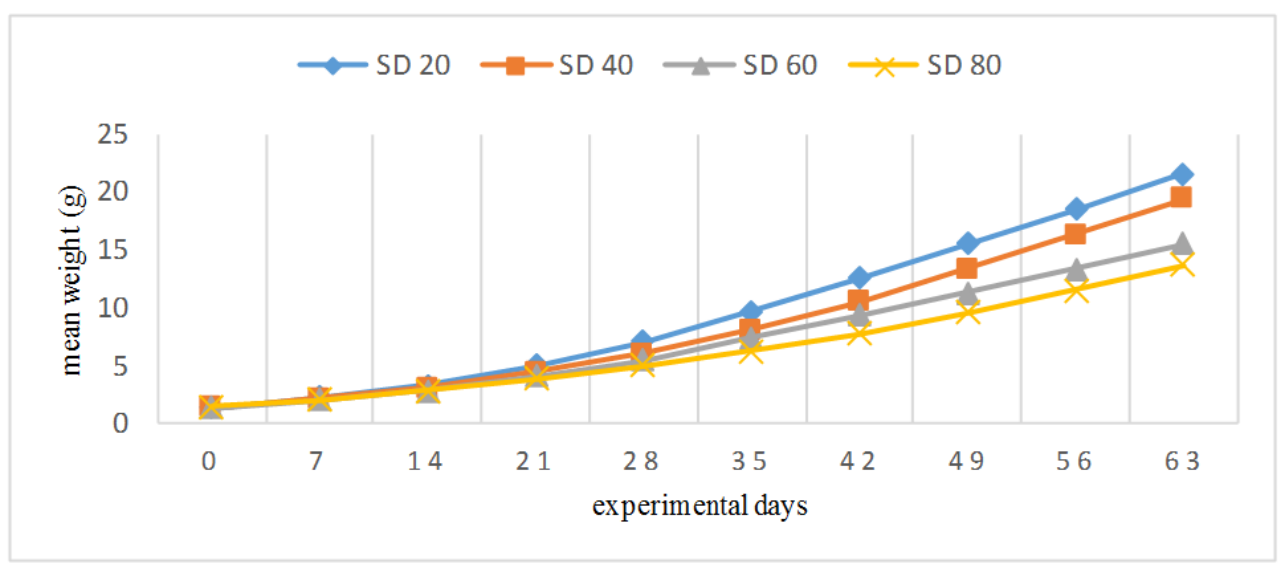


Fig.2 Experimental site at Suryalanka in Guntur district, Andhra Pradesh, India

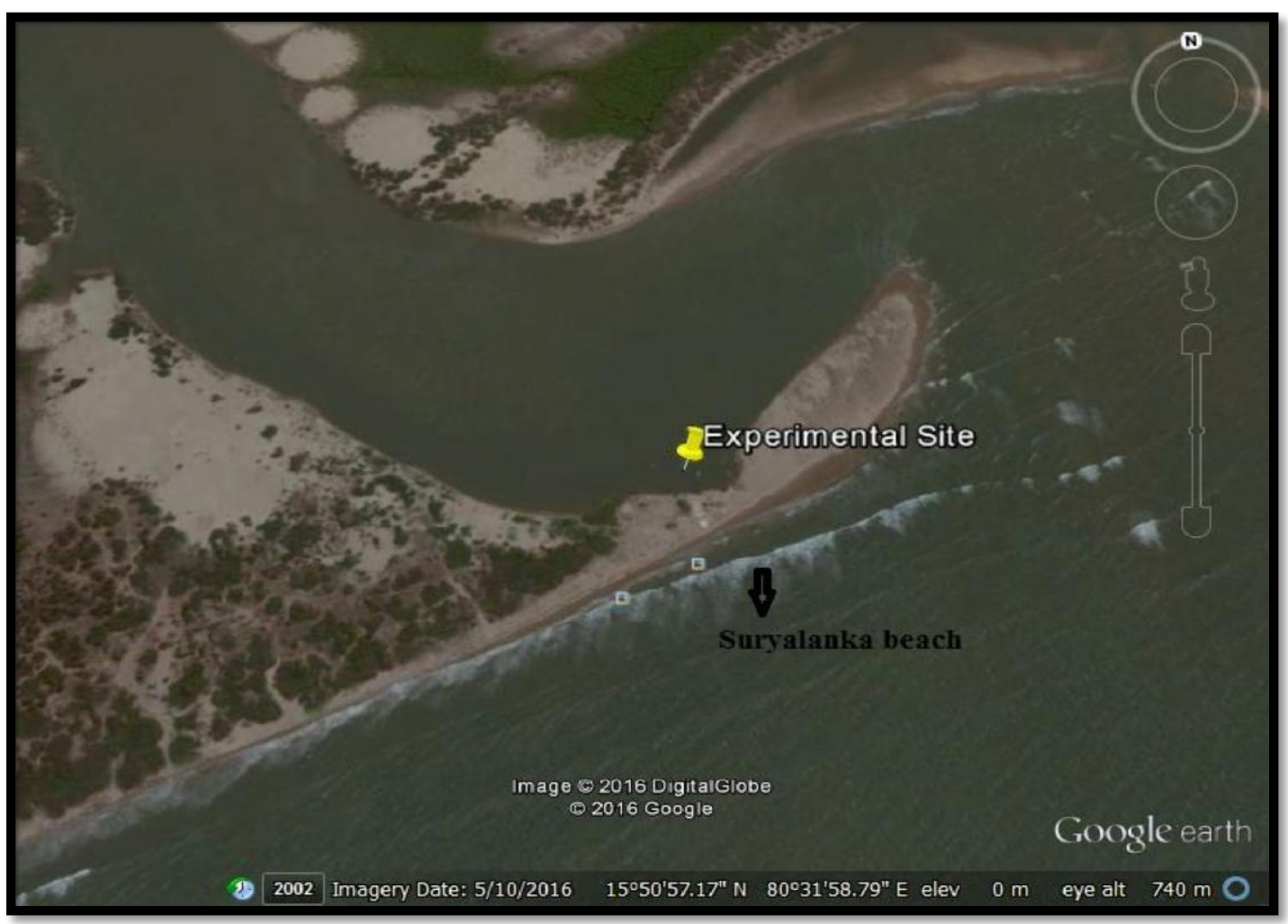

Fig.3 Experimental setup (Floating net cages)

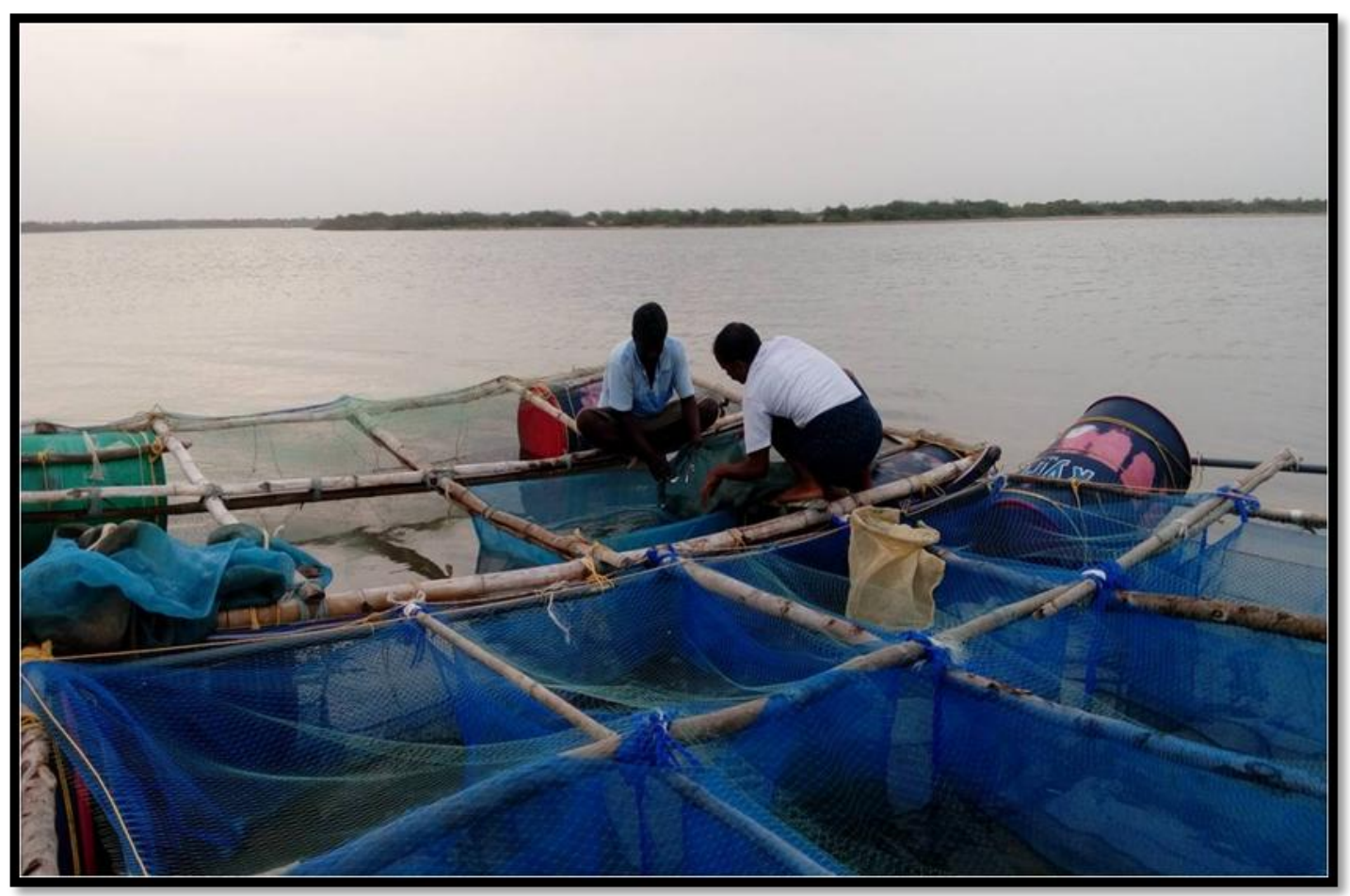


Fig.4 Seabass, Lates calcarifer seed

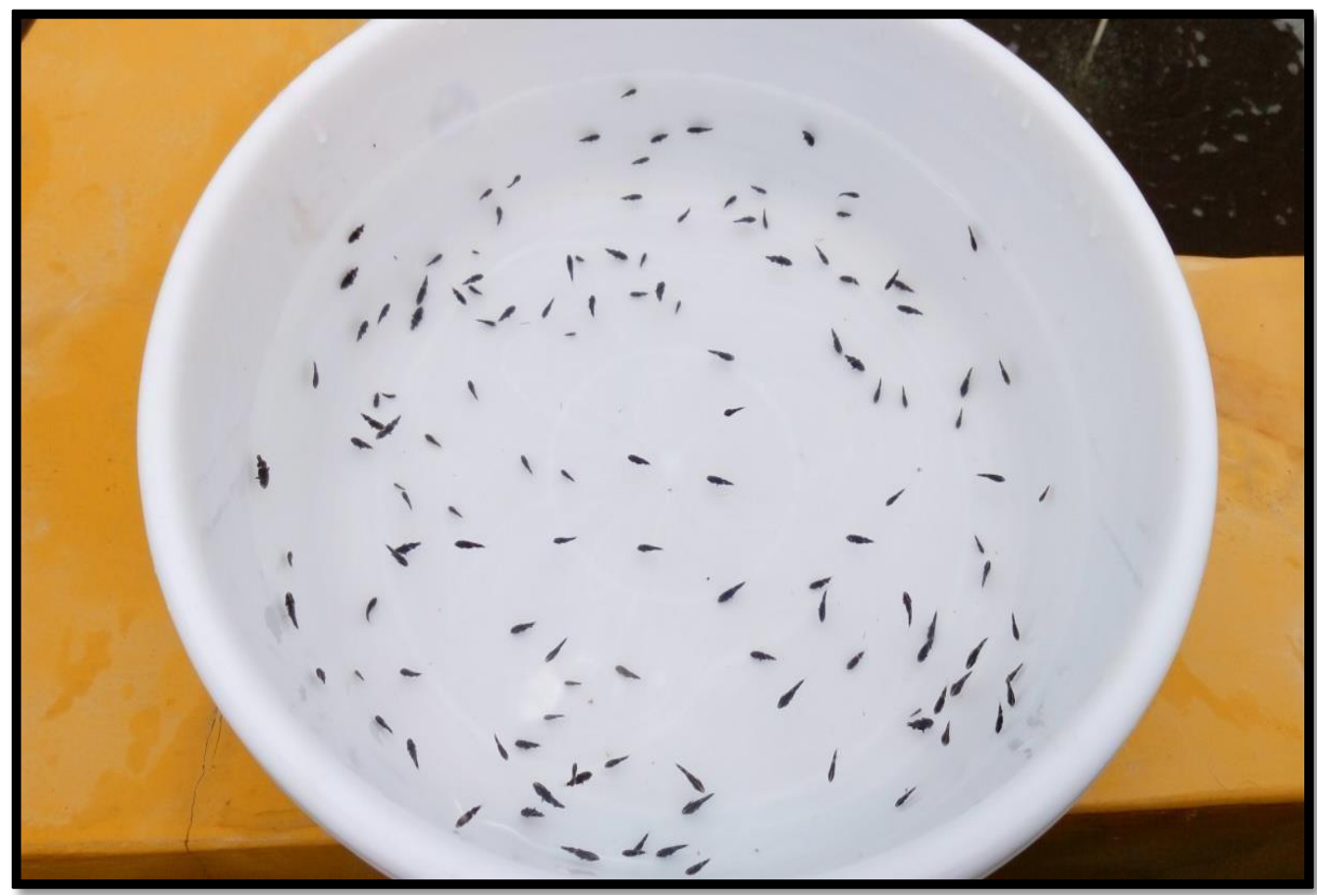

Fig.5 Cage nets checking and cleaning

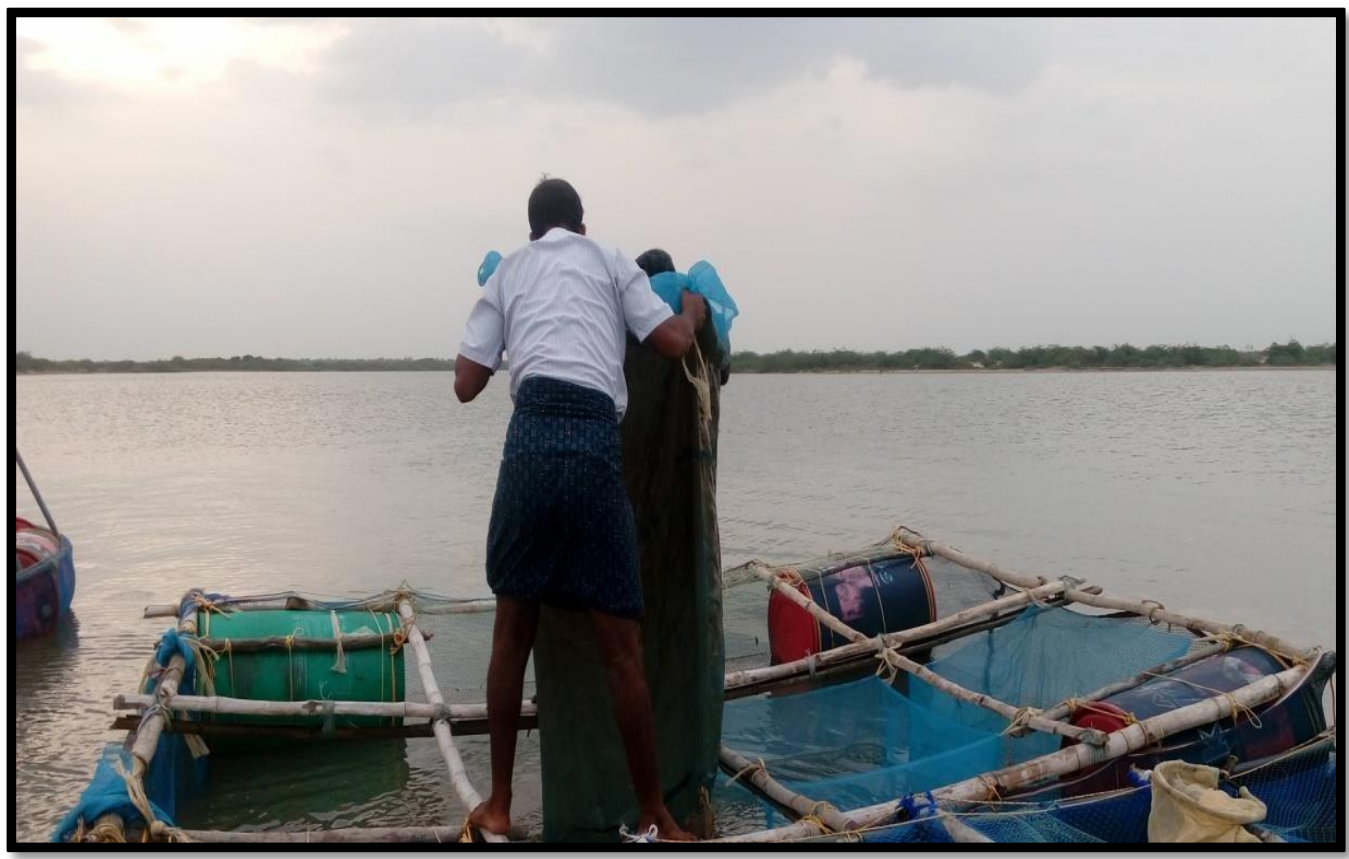

Kestemont et al., (2003) also reports slow growth rates at higher densities in post-larvae of European seabass. There are reports of growth reduction in fish with increasing stocking density. This may be due to crowding. Under crowded conditions at higher stocking densities, fish suffer stress as a result of aggressive feeding interaction and 
eat less, resulting in growth retardation (Sinha and Ramachandran, 1985; Bjoernsson, 1994). In the present study also fish growth was decreased with increasing stocking densities. Growth in terms of final weight, weight gain and SGR of seabass was higher in SD 20 compare to fish in higher stocking densities. The causes might be competition for food and habitat at higher density. Similar observations was made in mahseer (Rahman et al., 2005); Labeo rohita, Cirrhinus mrigal and Cyprinus carpio (Haque et al., 1991, 1993, 1994); punti (Kohinoor et al., 1994); mahseer (Islam, 2002); Labeo calbasu (Rahman and Rahman, 2003). In the present study highest survival was recorded in lowest stocking density (SD $20)$ in seabass. Survival rate decreased with increasing stocking density. These results are similar with the findings of Sayeed et al., (2008) in Thai pangus and Cremer et al., (2002) in pangasius catfish. Lower density gave larger size and higher survival rate in Clarias macrocephalus as reported by Mollah (1985). Lower stocking density showed higher survival of C.angullaris as reported by Ita et al., (1989). In the present study survival rate of seabass was significantly higher in SD 20. Similar observations were made in mahseer (Rahman et al., 2005); climbing perch (Kohinoor et al., 2009). The highest weight gain and survival rate of Heteropneustes fossilis in lower stocking density was reported by Narejo et al., (2005 and 2010). In Trachinotus blotchi also lower stocking densities resulted in higher growth and survival (Hannibal et al., (2011). The relatively high mortality in the present study may be due to cannibalism. Kailasam et al., (2002) also reported cannibalism as reason for high mortality in seabass during nursery rearing. In the present study average daily weight gain between 0.194 and 0.321 is recorded in seabass. Similar observations were made by the Philipose et al., (2010) in nursery rearing of seabass. In their study ADWG at the end of the experimental period was $0.24 \mathrm{gm}$. ADWG in the present study was found to be high in low stocking density (SD 20) throughout the study period. Earlier studies have also reported decreased ADWG with increasing stocking densities in largemouth bass, Micropterus salmoides (Petit et al., 2001) and in silver perch, Bidyanus bidyanus (Rowland et al., 2004).Size and water temperature may also influence the SGR. In the present study, SGR of seabass ranged between $2.13 \pm 0.02$ (SD 80) to $2.72 \pm 0.06$ (SD 20). SGR decreased at the highest stocking density of $80 \mathrm{fish} / \mathrm{m}^{3}$. Similar observations were made by Ardiansyah and Fotedar Ravi (2016) in seabass reared in integrated recirculating aquaculture Systems. In the present study seabass at lowest stocking density (SD 20) utilised the feed most efficiently and showed better FCR than the other groups. Feed conversion ratio (FCR) was significantly affected by fish stocking densities in this study. This finding was similar with that obtained by Moniruzzaman et al., (2015b) in caged Thai silver barb, Barbonymus gonionotus and Mondal et al., (2010) in caged Thai climbing perch, Anabas testudineus and Gibtan et al., (2008) in caged Nile tilapia, Oreochromis niloticus at 50 and $100 \mathrm{fish} / \mathrm{m}^{3}$. However, Mondal et al., (2010) observed lower FCR of 0.79 in combined cage culture of Thai climbing perch and tilapia after 120 days culture. Liti et al., (2005) opined that high density stocked fishes might have lower ability to convert given feed to flesh than fish stocked with low density in terms of growth. Philipose et al., (2010) reported FCR of 1.15 in 45 day nursery rearing of Asian seabass in indoor cement tanks. As the present studies were conducted in closed bay and there may be some feed wastage in the open system, higher FCR of $2.60 \pm 0.09$ was recorded. Similar results were reported by Siddiqui et al., (1997) in hybrid tilapia reared in concrete tanks with 50 fish $/ \mathrm{m}^{2}$ where the FCR was 2.59. In the present study, there was an increasing trend of 
biomass with increasing stocking density. In the present study production is more in 80 fish $\mathrm{m}^{3}$ in terms of biomass as well a number of $\mathrm{seed} / \mathrm{m}^{3}$ for seabass. This study shows a strong trend that final production increased with increasing stocking density. These findings are in agreement with those reported by Cruz and Ridha (1989) and Watanabe et al., (1990) for tilapia.

Present study revealed that stocking density had significant impact on growth and final mean weight. Survival rate, average daily weight gain and specific growth rate were higher in fish held at low stocking density (SD 20) when compared to high stocking density. Feed conversion ratio was lower in low density group (SD 20). However, final production in terms of total biomass was higher in high density group (SD 80).

\section{Acknowledgements}

I am grateful to Central Marine Fisheries Research Institute (CMFRI) - Karwar for providing necessary facilities to conduct the study. I profess my heartfelt gratefulness and sincere regard to my esteemed guide Dr. B. Chamundeswari Devi, Principal Scientist \& Head, Fishery Research Station, Kakinada.

\section{References}

Abou, Y., Fiogbe, E. D. and Micha, J. 2007. Effects of stocking density on growth, yield and profitability of farming Nile tilapia (Oreochromis niloticus L.) fed Azolla diet, in earthen ponds. Aquaculture Research 38: 595 - 604.

AOAC, 1995. Official Methods of Analysis of the Association of Official Analytical Chemists. Washington, DC. pp.101.

APHA (American Public Health Association), 1995. Standard methods for the examination of water and waste water, $19^{\text {th }}$ ed. American Public Health Association, Washington, DC.

Ardiansyah and Fotedar Ravi. 2016. Water quality, growth and stress responses of juvenile barramundi (Lates calcarifer Bloch), reared at four deferent densities in integrated recirculating aquaculture systems, Aquaculture, doi:10.10.16/ j.aquaculture. 2016.03.001.

Baldwin, K., Celikkol, B., Steen, R., Michelin, D., Muller, E. and Lavoie, P. 1999. Open ocean aquaculture engineering: mooring \& net pen deployment. Mar.

Bardach, J.E., Ryther, J.H. and McLarney, W.O. 1972. Aquaculture: The Farming and Husbandry of Freshwater and Marine Organisms, Wiley-Interscience, New York, p.868.

Beveridge, M. 2004. Cage Aquaculture. Blackwell Publishing. Third Edition, pp. 111158.

Bjoernsson, B. 1994. Effect of stocking density on growth rate of halibut (Hippoglossus hippoglossus L.) reared in large circular tanks for three years. Aquaculture 123, 259-271.

Boonyaratpalin, M. 1997. Nutrient requirements of marine food fish cultured in Southeast Asia. Aquaculture, 151: 283-313.

Boonyaratpalin, M. and Williams, K. 2002. Asian seabass Lates calcarifer. In: Webster, C. D. and Lim, C. (Eds.), Nutrient requirements and feeding of finfish for Aquaculture, $\mathrm{CAB}$ Publishing, p. 40-50.

Brown, M.E. 1946. The growth of brown trout (Salmo trutta Linn.). 1. Factors influencing the growth of trout fry. $J$. Exp. Biol., 22: 118-129.

Chua TE, Teng SK (1979) Relative growth and production of the estuary grouper Epinephelus salmoides under different stocking densities in floating net-cages. Mar Biol54:363-372. 
Costa C., Menesatti P., Rambaldi E., Argenti L. and Bianchini M. L. 2013 Preliminary evidence of colour differences in European sea bass reared under organic protocols. Aquaculture Engineering 57:82-88.

Cremer MC, Jian Z and Enhua Z 2002. Pangasius catfish production in ponds with soy-Based Feeds American Soybean Association, URL: http://www.soyaqua.org/pdf2/02.

Cruz, E.M. and Ridha, M., 1991. Production of the tilapia Oreochromis spirulus $\mathrm{Gu}$ "nther stocked at different densities in sea cages. Aquaculture 99, 95- 103. pp. 83-96.

Effect of stocking density on survival and growth. Indian Journal of GeoMarine Sciences. Vol 44 (10), pp 1540-1544.

Fairchild, E.A., Howell, W.H., 2001. Optimal stocking density for juvenile winter flounder Pseudopleuronectes americanus. J World Aquac Soc. 32, 300-308.

Fredriksson, D., Swift, R.., Muller, E., Baldwin, K. and Celikkol, B. 1999. Open ocean aquaculture engineering: system design and physical modelling. Mar. Technol. Soc. J., 34: 41-52.

Gibtan A., Getahun A. and Mengistu S. 2008. Effect of stocking density on the growth performance and yield of Nile tilapia (Oreochromis niloticus) in a cage culture system in Lake Kuriftu, Ethiopia. Aquaculture Research 39:1450-1460.

Hannibal MC, Amparo LF and Aurelio AC 2011. Effect of Stocking Density on Growth Performance, Survival and Production of Silver Pompano, Trachinotus blochii (Lacépède, 1801) in Marine Floating Cages. Asian Fisheries Science 24:321-330.

Haque, M.Z., Rahman, M.A., Hossain, M.M. 1993. Studies on the effect of stocking densities on the growth and survival of mrigal (Cirrhinus mrigala) fry in rearing ponds. Bangladesh J. Zool. 21 (1), 51-58.

Haque, M.Z., Rahman, M.A., Hossain, M.M. and Rahman, M.A. 1994. Effect of stocking densities on the growth and survival of mirror carp, Cyprinus carpio var. specularis in rearing ponds. Bangladesh J. Zool. 22, 109- 116.

Haque, M.Z., Rahman, M.A., Sultana, N., Rahman, M.A. 1991. Growth and survival of rohu (Labeo rohita Ham.) spawn at different stocking densities in nursery ponds. Bangladesh J. Fish. 14, $107-113$.

Hengsawat, K., Ward and F.J., Jaruratjamorn, P. 1997. The effect of stocking density on yield, growth and mortality of African catfish (Clarias gariepinus Burchell 1822) cultured in cages. Aquaculture 152, 67-76.

Islam, M.S. 2002. Evaluation of supplementary feeds for semi intensive pond culture of mahseer, Tor putitora (Hamilton). Aquaculture 212, 263-276.

Ita EO, Madu CT, Omorinkoba WS and Pandogari A. 1989. Preliminary estimator of the survival rate of Clarias angullaris fry under outdoor hatchery management system. Annu. Rep. Natl. Inst. Fish. Res. (Nigeria), 88-94.

Kailasam, M., Thirunavukkarasu, A. R., Mathew Abraham, Kishore Chandra, P. and Subburaj, R. 2002. Influence of size variation and feeding on cannibalism of Asian seabass Lates calcarifer (Bloch) during hatchery rearing phase. Indian J.Fish. 49: 107-113.

Kestemont, P., Jourdan, S., Houbart, M., Mélard, C., Paspatis, M.,Fontaine, P., Cuvier, A., Kentouri, M. and Baras, E. 2003.Size heterogeneity, cannibalism and competition in cultured as a factor affecting the survival of intensively cultured bass predatory fish larvae: 
biotic and abiotic influences. Aquaculture, 227 (1-4): 333-356.

Kilambi, R.V., Adams, J.C., Brown, A.V. and Wickizer, W.A. 1977. Effects of stocking density and cage size on growth feed conversion and production of rainbow trout and channel catfish. Prog. Fish. Cult. 39: 62-66.

Kohinoor AHM, Jahan DA, Khan MM, Ahmed SU and Hussain MG. 2009. Culture potentials of climbing perch, Anabas testudineus (Bloch) under different stocking densities at semiintensive management. Bangladesh Journal of Fisheries Research 13:115120.

Kohinoor, A.H.M., Haque, M.Z., Hussain, M.G. and Gupta, M.V. 1994. Growth and survival rate of Thai punti, Puntius gonionotus (Bleeker) spawn in nursery ponds at different stocking densities. $J$. Asiat. Soc. Bangladesh, Sci. 20, 65-72.

Liti D. M., Fulanda B., Munguti J. M., Straif M., Waidbacher $H$. and Winkler G. 2005 Effect of open-pond density and caged biomass of Nile Tilapia (Oreochromis niloticus, L.) on growth, feed utilization, economic returns and water quality in fertilized ponds. Aquaculture Research 36: 1535-1543.

Mollah MFA. 1985. Effects of stocking density and water depth on the growth and survival of freshwater catfish, Clarias macrocephalus Gunther larvae. Indian Journal of Fisheries 32: 1-17.

Mondal M. N., Shahin J., Wahab M. A., Asaduzzaman M. and Yang Y. 2010 Comparison between cage and pond production of Thai climbing perch (Anabas testudineus) and tilapia (Oreochromis niloticus) under three management systems. Journal of the Bangladesh Agricultural University 8:313-322.

Moniruzzaman M., Uddin K. B., Basak S., Bashar A., Mahmud Y., Zaher M, Lee S and Bai SC 2015b. Effects of stocking density on growth performance and yield of Thai silver barb (Barbonymus gonionotus) reared in floating net cages in Kaptai Lake, Bangladesh. $A A C L$ Bioflux 8(6):999-1008.

Moniruzzaman M., Uddin K. B., Basak S., Bashar A., Mahmud Y., Zaher M, Lee S and Bai SC 2015b. Effects of stocking density on growth performance and yield of Thai silver barb (Barbonymus gonionotus) reared in floating net cages in Kaptai Lake, Bangladesh. AACL Bioflux 8(6):999-1008.

Narejo NT, Dayo A, Dars BA, Mahesar H, Laghari MY and Lashari PK 2010. Effect of stocking density on growth and survival rate of Labeo rohita (Hamilton) fed with formulated feed. Sindh University Research Journal (Sci.Ser.) 42(1):35-38.

Narejo NT, Salam MA, Sabur MA and Rahmatullah SM. 2005. Effect of stocking density on growth and survival of indigenous catfish, Heteropneustes fossilis (Bloch) reared in cemented cisterns fed on formulated feed. Pakistan Journal of Zoology 37 (1): 4952.

Petit, G., Beauchaud, M. and Buisson, B. 2001. Density effects on food intake and growth of Largemouth bass (Micropterus salmoides). Aquaculture Research 32: 495 - 497.

Philipose, K. K., Krupesha Sharma, R. S., Sadhu, N., Vaidya, N. G. and Syda Rao, G. 2010. Some aspects of nursery rearing of the Asian seabass (Lates calcarifer, Bloch) in indoor cement tanks. Indian J. Fish., 57(4): 61-64.

Rahman MA, Mazid MA, Rahman MR, Khan MN, Hossain MA. And Hussain MG. 2005. Effect of stocking density on survival and growth of critically endangered mahseer, Tor putitora 
(Hamilton) in nursery ponds. Aquaculture 249:275-284.

Rahman MA, Mazid MA, Rahman MR, Khan MN, Hossain MA. And Hussain MG. 2005. Effect of stocking density on survival and growth of critically endangered mahseer, Tor putitora (Hamilton) in nursery ponds. Aquaculture 249:275-284.

Rahman, M.R. and Rahman, M.A. 2003. Studies on the growth, survival and production of calbasu (Labeo calbaus Ham.) fry at different stocking densities in primary nursing. Bull. Fac. Sci., Univ. Ryuyus, Jpn. 76, 245-255.

Rimmer, M. A. and Russell, D. J. 1998. Aspects of the biology and culture of Lates calcarifer, In: De Silava, S. S. (Ed.), Tropical Mariculture, Academic Press, U.S.A., p: 449-476.

Rowland S.J., Allan G.L., Hollis M. and Pontifex T. 2004. Production of silver perch (Bidyanus bidyanus) fingerlings at three stocking densities in cages and tanks. Aquaculture 229, 193-202.

Sadhu N, Sharma SK, Joseph S, Dube P. and Philipose K. 2015. First results of culture of seabass, Lates calcarifer in open sea floating net cages in India:

Sayeed MAB, Hossain GS, Mistry SK and Huq KA. 2008. Growth performance of Thai pangus (Pangasius hypophthalmus) In polyculture system using different supplementary feeds. University Journal of Zoology, Rajshahi University 27: 59-62.
Siddiqui, A. Q., Al-Habri, A. H and Al Hafedh Y. S. 1997. Effect of stocking density on patterns of reproduction and growth of hybrid tilapia in concrete tanks in Saudi Arabia. Asian Fisheries science 10: 41-49.

Sinha, V. R. P. and Ramachandran, V. 1985. Freshwater fish culture. Indian Council of Agricultural Research, New Delhi, India.

Snedecor, G. W. and Cochran, W. G. 1989. Statistical methods, 8th Edition, Iowa state university Press, Ames, Iowa.

Sukumaran, K., Thirunavukkarasu, A. R., Kailasam, M., Sundaray, J. K., Subburaj, R and Thiagrajan, G. 2011. Effect of stocking density on size heterogeneity and sibling cannibalism in Asian seabass Lates calcarifer (Bloch, 1790) larvae. Indian J. Fish., 58(3):145147.

Watanabe W.O., Clark J.H., Dunham J.B., Wicklund R.I. and Olla B.I. 1990. Production of fingerling Florida red tilapia (Tilapia hornorum $\times T$. mossambica) in floating marine cages. The Progressive Fish-Culturist 52,158161 .

WRI, 1998. World Resources 1998-1999. Oxford University Press, Oxford.

Yue, G.H., Zhu, Z.Y. and Lo, L.C. 2009. Genetic variation and population structure of Asian seabass (Lates calcrifer) in the Asia Pacific region. Aquaculture, 293; 22-28.

\section{How to cite this article:}

Suresh, G., M. Raveendra, K. Jyotsna Rajeswari, B. Chamundeswari Devi, M. Anusha, D. Venkatesh, D. Ravindra Kumar Reddy and Madhavan, N. 2018. Growth and Survival in Nursery Rearing Phase of the Asian Seabass (Lates calcarifer, Bloch) under Different Stocking Densities in Floating Net Cages. Int.J.Curr.Microbiol.App.Sci. 7(05): 2061-2072. doi: https://doi.org/10.20546/ijcmas.2018.705.242 